\title{
実践研究
}

\section{自閉スペクトラム症のある青年における 「悪質商法の勧誘を断る行動」の獲得と般化の検討}

\begin{abstract}
山本 多佳実*井 澤 信 三**
本研究は、自閉スペクトラム症のある青年 3 名に対して「悪質商法の勧誘を断る行動」の 指導を行い、(1) 悪質商法の勧誘を断る行動の獲得、(2) 直接指導をしていない悪質商法への 般化、(3) 悪質商法と悪質商法ではないものの適切な弁別、の 3 つを検討することを目的とし た。指導は (1) ルールの提示、(2) シミュレーション訓練、(3)トレーナーからのフィードバッ

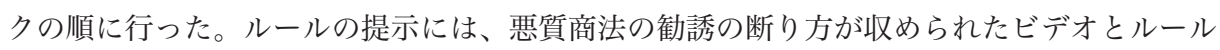
シートを用いた。シミュレーション訓練は、外出条件と在宅条件の訓練を行った。各条件に は悪質商法課題と非悪質商法課題を用意し、訓練を行った。訓練後にトレーナーからフィー ドバックが行われた。結果は 3 名全員が指導した行動を獲得し、悪質商法と非悪質商法課題 の弁別ができた。 3 名中 2 名は対人般化、1 名は条件般化にも成功し、1名に関しては実際場 面での般化のエピソードも確認された。
\end{abstract}

キー・ワード : 自閉スペクトラム症 犯罪被害予防 消費者教育 悪質商法 ルール支配行動

\section{I . 問題と目的}

警察庁（2018）によると、悪質商法とは、一般消費 者を対象に組織的・反復的に敢行される商取引で、そ の商法自体に違法または不当な手段・方法が組み込ま れたものをいう。発達障害のある人たちにおいても、 質問に対して返事ができるなどの簡単なコミュニケー ションが成立する程度の障害である場合、悪質商法の 被害に遭うリスクに十分に気をつけなくてはならない と大石（2005）は指摘している。また、Howlin（2000） は知的能力障害が軽度もしくは伴わない自閉スペクト ラム症 (autism spectrum disorder; 以下、ASD とする) の成人の犯罪問題について、知らない間に犯罪に巻き 込まれる事例があると指摘している。さらに、ASD の ある人たちの障害特性から、井澤・山本・半田 (2011) は「騙される」といった可能性の高さを示唆し、被害 を受けないような対応、例えば消費者教育なども、支 援に含まれると述べている。以上のことから、ASD の ある人たちに悪質商法の被害を未然に防ぐための指導 の必要性があるといえよう。

これまで、犯罪被害を回避する行動は「自己防衛（self-

*デリバリー型個別療育支援 TRIAL

** 兵庫教育大学大学院 protection）スキル」として研究がなされてきた（e.g., Poche, Brouwer, \& Swearington, 1981)。Miltenberger, Roberts, Ellingson, Galensky, Rapp, Long, and Lumley （1999）は、軽度から中程度の知的能力障害のある5 名 の女性に対して、身近な人からの性的虐待に対する自 己防衛スキルの指導を行った。指導では生活場面をシ ミュレートした環境でロールプレイが行われ、その結 果対象者は、指導された「虐待を受けた時にNOとい う」「その場を立ち去り、先生や両親に報告する」など のスキルを獲得した。さらに、数名の対象者には、実 際に生活する場面で般化テストをした際にも標的行動 が生起した。このことから、自己防衛スキルの指導 は、実際の生活場面をシミュレートした環境で行うこ とが有効であるといえる。

しかし、ASD を含む障害のある人たちへの悪質商 法被害予防の指導には、課題として (1) 悪質商法の巧 妙かつ複雑な勧誘を断ることができないこと（佐分， 2011）、(2)在宅時に遭遇するものや外出時に遭遇する ものなどさまざまな種類があり（上迫, 2008）、広汎な刺 激に対して般化が求められること、(3)悪質商法と悪質 商法ではないものの弁別に困難が生じること（佐分， 2011）などが考えられる。このような状況に対応でき る行動の獲得に有効な指導法を検討する必要がある。 
ところで、標的行動を形成し般化を促す指導とし て、ルールを用いた指導がある。Skinner（1969）によ るとルールとは、行動随伴性を記述した言語刺激のこ とをいう。具体的な例としては、「あの人に話しかけ るとお菓子がもらえますよ」というような先行刺激一反 応-結果を表した記述のことである。Malott（1988）は、 ルールに関して確立操作 (establishing operation; 以 下、EO とする)1) の機能を強調している。EO とはあ る事象あるいは事象の強化子としての効力を変え、同 時にその強化子に基づく行動の頻度を一時的に変える 環境変化のことをいう（Michael, 1982）。指導にルー ルを用いる利点としては、(1) ルールが EO として機能 した場合、ルールによって行動を制御することが可能 であること（杉山・島宗・佐藤・マロット・マロット， 2013)、(2) 指導した刺激だけではなく異なる刺激に対 する般化が成立すること（井澤, 2003; 須藤, 2009）が 挙げられる。このことから、ルールによって系統的に 行動を制御することができたならば、障害のある人が 悪質商法の被害を受けた際の課題である広汎な刺激に 対する般化に有効ではないかと考えられる。

一方で、自己防衛スキルの指導に関して Wurtele （1990）は、指導の副作用に関しても考慮する必要があ ると指摘している。例えば、指導を受けた対象者たち が、家族や友人に対しても犯罪加害者と同様の対応に なることや、不特定多数の人々に対して恐怖感情を抱 くようになることである。悪質商法被害予防の指導の 場合には、道に迷い、困っている人が話しかけてくる 時や、近所の人が回覧板を持って訪ねてくる時という ような悪質商法ではない場合にも、悪質商法の販売員 と同様の対応をしてしまう恐れがある。このような問 題に対する対策として、ルールの提示方法の工夫が求 められると考えられる。Persicke, Tarbox, Ranick and St. Clair（2013）は、ASDのある児童に対して、他者か らの嫌味や皮肉な発言とそうではない発言を弁別し適 切に対処する行動の指導にルールを用いた。ルールの 提示には、ルールを活字化したカードと 10 秒程度の ビデオが使用された。その結果、標的行動の獲得と、 指導をしていない発言や指導をしていない人に対する 般化に有効であった。Persicke et al. (2013) の知見か ら、ルールを悪質商法と判断するための記述を活字化 することに加え、ビデオを用いて提示し「悪質商法の 勧誘を断る行動」の指導を行い、指導をしていない悪 質商法に対する般化と、悪質商法ではないものに対す る適切な弁別を促す必要性がある。

そこで本研究では、ASD のある青年に対してルー
ルを用いて悪質商法の勧誘を断る行動の指導を行い、 (1) 悪質商法の锥誘を断る行動の獲得、(2) 直接指導を していない悪質商法に対する般化、(3)悪質商法と悪 質商法ではないものの適切な弁別を検討することを目 的とする。

\section{II. 方 法}

\section{1. 対象者}

本研究の対象者はASD と医学的診断を受けた男性 3 名であった。本研究は公立相談機関において「高校 生以上に向けた悪質商法対応プログラム」として参加 募集を行い、その応募者から研究に参加する対象者を 決定した。対象者 3 名中 2 名は成人していたため、保 護者の許可を得なくてもローン契約などをすることが できた。全員が自分専用の携帯電話を所持していた。 全員が知的能力障害の診断はなく、小学校、中学校、 高等学校において通常学級に在籍していた。全員が学 校教育において悪質商法に関する授業を履修済みで あった。

（1）対象者 $\mathrm{A}$ ：指導開始時の年齢は 20 歳で、四 年制大学の文系学部 3 年生であった。通学には電車と バスを利用していた。7歳の時に医療機関において高 機能広汎性発達障害と診断されていた。公立相談機関 には、10 歳の頃より保護者とともに相談に通ってい た。普通自動車免許を取得しており、免許証を常に携 帯していた。

指導開始直後から就職活動を開始しており、民間企 業が企画する就活セミナーや合同説明会には頻繁に参 加していた。コミュニケーションの特徴として、本人 は「誰とでもどんな時でも流暢に会話することができ る」と発言していたが、実際には、他者から急に話し かけられ応答を求められると、声が小さくなり、何を 言っているのかわからないことがあった。

（2）対象者 B：指導開始時の年歯は 17 歳で、高 等学校 2 年生であった。通学には自転車を利用してい た。1歳半検診の時に障害の疑いがあることを指摘さ れ、その後、3 歳の時に医師から自閉症であると診断 された。公立相談機関には、10 歳の頃より保護者とと もに相談に通っていた。

行動的な特徴として、一人でいる際には独り言を 言つたり、音楽を聴きながら歌つたりするような様子 がみられた。コミュニケーションの特徴として、自分 から他者に話しかけることがあったが、一方的で相手 が反応していなくても話し続けることがあった。相手 からの問いかけに関してはうまく返せない時があり、 
そのような時は声が小さくなり下を向いてしまうこと があった。

（3）対象者 C：指導開始時の年歯令は20歳であっ た。定時制高等学校を卒業し、就労移行支援事業所に 所属していた。小学校 3 年生の時に医療機関において 高機能自閉症と診断された。通勤には電車とバスを利 用していた。原動機付自転車免許を取得しており、免 許証を常に携帯していた。

行動的な特徴として、自分の好きな特撮ヒーローの ポーズを突然前触れもなくはじめたり、独り言を言い ながら周囲をキョロキョロしたりするような様子がみ られた。また、何度も忘机物がないか荷物を確認した り、本研究の日程について何度もトレーナーに聞いた りするような様子がみられた。コミュニケーションの 特徴としては、知人には自分から話しかけることがで きていた。意見を求められることがあると、瞬時に対 応できない場合は数秒ほど硬直することがあった。

2. インフォームド・コンセントおよびインフォーム ド・アセント

本研究の開始前に、対象者に向けて「悪質商法の勧 誘を断る行動の指導に関するインフォームド・コンセ ントおよびインフォームド・アセント」を第 1 著者が 口頭と文書を用いて行った。その際に、(1) 指導にはト レーナーが販売員として対象者に話しかけ契約を促す ことがあること、(2)指導中にもし誤って契約してし まってもそれは実際の契約とは異なり、金銭のやりと りなどは発生しないこと、(3)本研究に参加すること が困難になった場合、いつでも研究への参加を中断で きること、(4) 個人情報の取り扱いについては十分に注 意すること、(5) 個人が特定されない形で、論文などに より発表を行うことがあることを説明した。その結 果、対象者全員から同意を得ることができた。

上記と同様の手続きで、未成年である対象者 B の保 護者に対してインフォームド・コンセントを行った。 その結果、対象者 B の保護者からも同意を得ることが できた。

\section{3. 指導期間および指導場所}

指導期間は $X$ 年 10 月から $X+1$ 年 3 月までの間であ り、2 週間に 1 回、約 45 分のプログラムを行った。本 研究はあらかじめ全 10 回のプログラムとして計画され ていた。1回のプログラムにつき、トレーニング (1) ルールの提示、(2) シミュレーション訓練、(3)トレー ナーによるフィードバックの一連の流机）を 2 回行つ た。指導場所は公立相談機関の一室（広さ約 $12 \mathrm{~m} \times$ $12 \mathrm{~m}$ ）を借用して行った。

\section{4. 悪質商法の勧誘を断る行動の指導条件}

本研究における「悪質商法の勧誘を断る行動」の指 導条件を Fig. 1 に示した。これは日本弁護士連合会・ 高齢者障害者の権利に関する委員会・消費者問題対策 委員会（2008）と警察庁（2018）を参考にして作成し た。悪質商法の中でもシミュレーション訓練において 再現可能で代表的なものとして、3 条件 10 課題を選定 した。これらを行動随伴性の観点から、「先行条件 1」 「先行条件 $2 」 「 反$ 応」結果」に分けた。これらの分 類・整理を、第 1 著者を含む 5 名で行った。 5 名の内 訳は、1名が学校教育において悪質商法に関する授業 を行う中学校社会科および高等学校公民科の教員免許 状所持者、4 名は応用行動分析学を専門とする教員に 指導を受けている大学院生であった。

悪質商法の条件は、家にいる際に遭遇する「在宅条 件」、外出している際に遭遇する「外出条件」メール や八ガキを媒介とする「その他条件」の 3 つに分類し た。各条件には、(1) 悪質商法の勧誘を行う「悪質商法 課題」、(2) 悪質商法ではない「非悪質商法課題」を設 けた。

在宅条件では、訪問販売 $A$ 、訪問販売 $B 、$ 非悪質商 法 A、非悪質商法 B の 4 つの課題を設けた。訪問販売 $\mathrm{A}$ は「突然、知らない業者が訪問してくるもの」、訪問 販売 B は「突然、“市役所から委託されて来た”など と言って業者が訪問してくるもの」、非悪質商法 A は 「自分が依頼するなどして、連絡をした業者がやってく るもの」、非悪質商法 B は「近所の人や親戚など知つ ている人が突然訪問してくるもの」であった。

外出条件では、キャッチセールス A、キャッチセー ルス B、非悪質商法 C、非悪質商法 D の 4 つの課題を 設けた。キャッチセールス $\mathrm{A}$ は「攵場でアンケー 卜に回答させ、住所などの個人情報を聞き出すもの」 キャッチセールス B は「事務所へ移動を促すもの小 非悪質商法 C は「道案内を頼まれることや観光客に力 メラのシャッターを押すことを依頼されるといつた、 困っている人に依頼をされるもの」、非悪質商法 D は 「腕章や名刺などを持っている大学院生やテレビ局員 にアンケートの回答を依頼されるもの」であった。

その他条件の悪質商法課題は、不当請求・当選商法 として「身に覚えのない請求や当選結果がメールで届

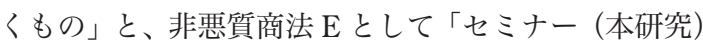
への出欠を問うメール」であった。

\section{5. 標的行動の評価基準}

各条件における評価基準を Table 1 に示した。標的 行動は在宅条件、外出条件ともに、悪質商法課題にお 


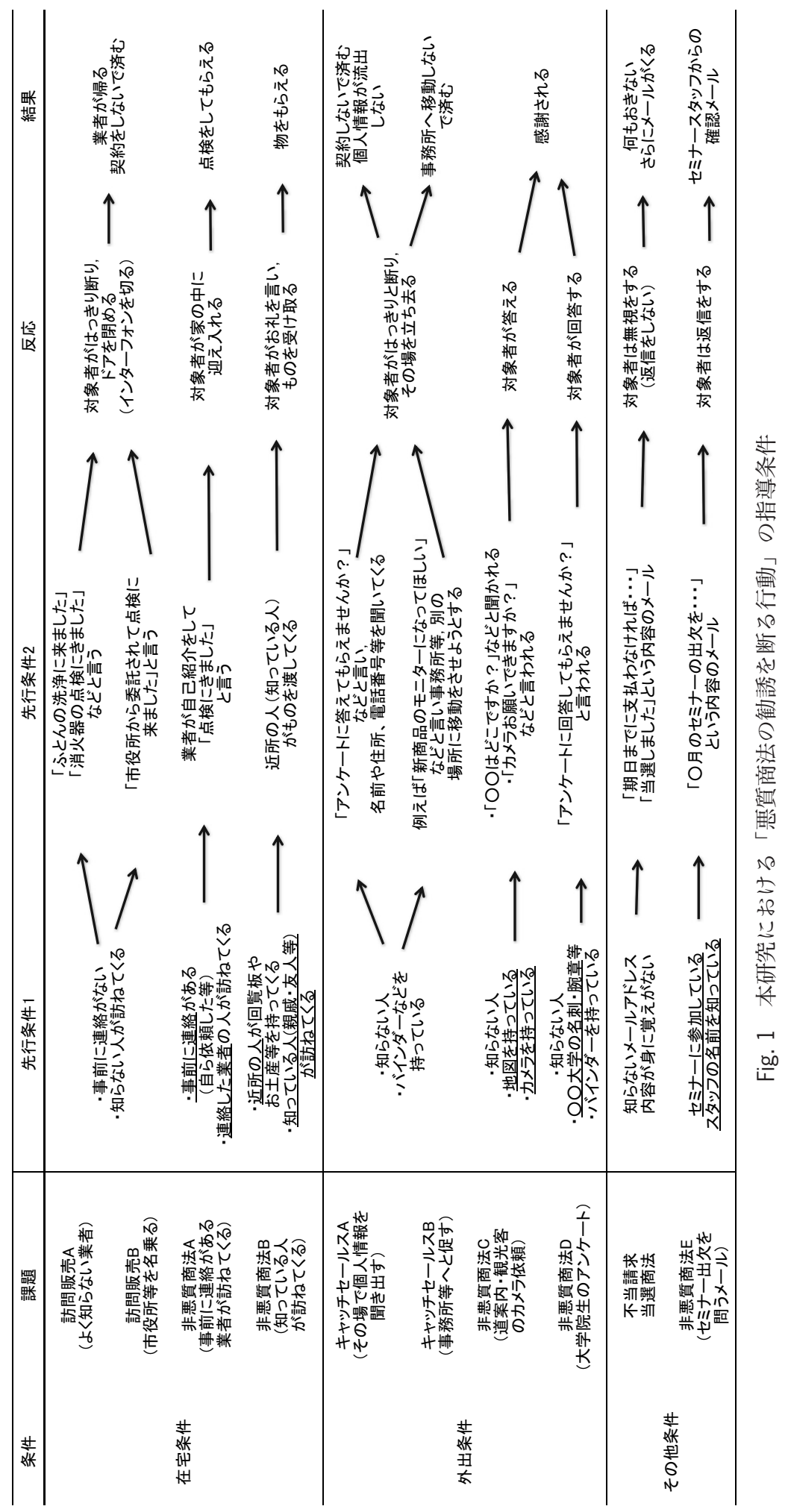


Table 1 標的行動の評価基準

\begin{tabular}{|c|c|c|}
\hline 条件（課題） & 点数 & 評価基準 \\
\hline \multirow{4}{*}{$\begin{array}{c}\text { 在宅条件 } \\
\text { (訪問販売 } \\
\mathrm{A} \cdot \mathrm{B})\end{array}$} & 3 & 正反応：玄関先ではっきりと断り（例：お断りします), ドアを閉める (インターフォンを切る) \\
\hline & 2 & 玄関先で「いいです」と言って断る・家の中に入れるが契約を促されると断る \\
\hline & 1 & 1 回断るが，契約する \\
\hline & 0 & 契約する・無反応 \\
\hline \multirow{2}{*}{$\begin{array}{c}\text { 在宅条件 } \\
\text { (非悪質商法 A) }\end{array}$} & 1 & 正反応：ものを受け取る \\
\hline & 0 & 誤反応 : はっきりと断る \\
\hline \multirow{2}{*}{$\begin{array}{c}\text { 在宅条件 } \\
\text { (非悪質商法 B) }\end{array}$} & 1 & 正反応 : 家の中に入れ, 点検をしてもらう・宅配便等を受け取り, サインをする \\
\hline & 0 & 誤反応 : はっきりと断る \\
\hline \multirow{4}{*}{$\begin{array}{c}\text { 外出条件 } \\
\text { (キャッチ } \\
\text { セールス } \mathrm{A} \cdot \mathrm{B})\end{array}$} & 3 & 口頭ではっきりと断り（例：お断りします）その場を立ち去る \\
\hline & 2 & 「いいです」と言って断る \\
\hline & 1 & 1 回断るが，契約（アンケートに回答・事務所等に移動）する \\
\hline & 0 & 契約（アンケートに回答・事務所に移動）する・無反応 \\
\hline \multirow{2}{*}{$\begin{array}{c}\text { 外出条件 } \\
\text { (非悪質商法 C) }\end{array}$} & 1 & 正反応 : 声をかけられ，援助する（道案内・記念撮影）・理由を説明し，謝罪し断る \\
\hline & 0 & 誤反応：はっきりと断る・無反応 \\
\hline \multirow{2}{*}{$\begin{array}{c}\text { 外出条件 } \\
\text { (非悪質商法 D) }\end{array}$} & 1 & 正反応 : アンケートに回答する・理由を説明し，謝罪して断る \\
\hline & 0 & 誤反応：はっきりと断る・無反応 \\
\hline \multirow{2}{*}{$\begin{array}{l}\text { その他条件 } \\
\text { (不当請求· } \\
\text { 当選商法) }\end{array}$} & 1 & 正反応 : メールを返信しない \\
\hline & 0 & 誤反応 : メールを返信する \\
\hline \multirow{2}{*}{$\begin{array}{c}\text { その他条件 } \\
\text { (非悪質商法 E) }\end{array}$} & 1 & 正反応 : メールを返信する（内容がはっきりと断るという悪質商法への対応の場合は誤反応） \\
\hline & 0 & 誤反応 : メールを返信しない \\
\hline
\end{tabular}

いて販売員に話しかけられた際にはっきり（例：必要 ありません、お断りしますなど）と断り、その場を立 ち去る（在宅条件の場合はドアを閉める）行動であっ た。標的行動の評価は、「口頭ではっきりと断り(例 : 必要ありません、お断りしますなど）その場を立ち去 る」を 3 点、「“いいです”と言つて断る」を 2 点、「1 回は断つているが、契約をする」を 1 点、「1回も断る ことなく契約をする・無反応（勧誘を受けても返答が ない)」を 0 点の 4 段階とした。例えば、外出条件の場 合、販売員に声をかけられた際にはっきりと「必要あ りません」と断り、その場を立ち去った場合には、3 点 の最高得点が与えられた。

その他条件のみ、メールの返信をする行動が標的行 動であった。悪質商法のメールが届いた際に、メール の返信をする行動が生起しない場合を 1 点、メール の返信をする行動が生起した場合を 0 点の 2 段階で あった。

非悪質商法課題においては、悪質商法と同様ではな い対応をした場合（例：道案内をした、丁寧に謝罪し 断った）を 1 点、悪質商法と同様の対応である「はっ きりと断る行動」がみられた場合を 0 点の 2 段階で評
価した。

この評価基準をもとにシミュレーション訓練中の対 象者の標的行動を評価し、得点化した。

6. 本研究の基本的なセッティング

（1）指導室のセッティング：指導場所である公 立相談機関の部屋の中央をパーテーション 3 枚で区切 り、パーテーションの 1 枚を可動式にしてドアに見立 て、ドアの内側に絨毯を敷いたところを自宅として、 ドアの外側の䋐毯を敷いていないスペースは通勤・通 学路とした。

（2）トレーナーの役割：本研究には、第 1 著者 を含む 5 名の大学院生が指導を行うトレーナーとして 参加した。そのうち 2 名がおもに外出条件を指導する 者、残りの 2 名がおもに在宅条件を指導する者であつ た。第 1 著者は全体指揮として、研究に対する全体的 な説明や、シミュレーション訓練中に各条件のトレー ナーに対して各条件の各課題を提示するタイミングの 指示を出す役割を担った。各条件の 2 名のトレーナー は、1名がメイントレーナー（Main Trainer; 以下、 MT とする) としてルールの提示等を行い、1名はサ ブトレーナー（Sub-Trainer；以下、STとする）として 
MT の補助を行った。MT と ST はセッションごとに役 割を交代していた。この MT と ST はシミュレーショ ン訓練時に 1 名が悪質商法の販売員役 (以下、販売員 役とする)、1名が非悪質商法課題を提示する役（以 下、非販売員役とする) であった。この販売員役と非 販売員役はシミュレーション訓練中に入替わること があった。

\section{7. ルール提示に使用した教材}

本研究のトレーニング期において、ルールを提示す るにあたり、ビデオとルールシート（以下、シートと する）の 2 つを用いた。ビデオの内容は Fig. 1 の指導 条件に則り、在宅条件では訪問販売 A、外出条件では キャッチセールス $\mathrm{A}$ ののであった。ビデオには対象 者と同年代の人物 2 名が登場し、1 名が販売員役、も う 1 名は対象者が注目する見本となる人物（以下、モ デルとする) であった。この 2 名は、対象者と顔見知 りではあったが本研究において直接的な指導をしてい ない人物であった。ビデオには、販売員がモデルのも とを訪ね商品の勧誘を行い、モデルがはっきりと断 り、販売員が立ち去るという一連の流れが収められて いた。

シートは Fig. 1 をもとに「悪質商法と判断するポイ ント」(先行条件 1)、「販売員からの勧誘の言葉」(先 行条件 2)、「はっきりと断る」(反応)、「その結果、悪 質商法との契約を回避できること」(結果) の一部が
空白になっているものが印刷されている A4 サイズの 用紙であった (Fig. 2 参照)。悪質商法と判断するポイ ントとして、外出条件は (1) 相手が名前を名乗らない (名乗ったとしても知っている人ではない)、(2)電話番 号や住所など個人情報を聞いてくる、(3)事務所や別の 場所へ案内しょうとしてくるという 3 つであった。在 宅条件は (1) 相手が名前を名乗らない（名乗ったとし ても知っている人ではない)、(2)事前に「○○の業者が 来る」などの連絡がない、(3) 電話番号や住所など個人 情報を聞いてくるという 3 つであった。なお、一般的 な悪質商法の販売員の特徵である「急に值段を下げた り、いわゆる“おいしい話”を持ってきたりする」な どは、指導前の段階で知識を持っていることが確認さ れていたため、彼らが挙げなかった内容をポイントと して示した。

上記のビデオとシートの 2 点の教材を、シミュレー

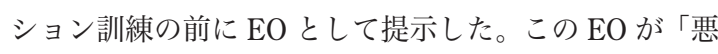
質商法の販売員が州る」「悪質商法との契約を回避で きる」という結果の強化価を高くするよう導入した。

\section{8. 手続き}

研究デザインは、一事例の実験デザインを採用し、 ベースライン期、トレーニング期、プローブ期、対人 般化プローブ期からなる $\mathrm{AB}+$ プローブデザインを用 いた。本研究はシミュレーション訓練を 1 回行うこと を 1 セッションとした。
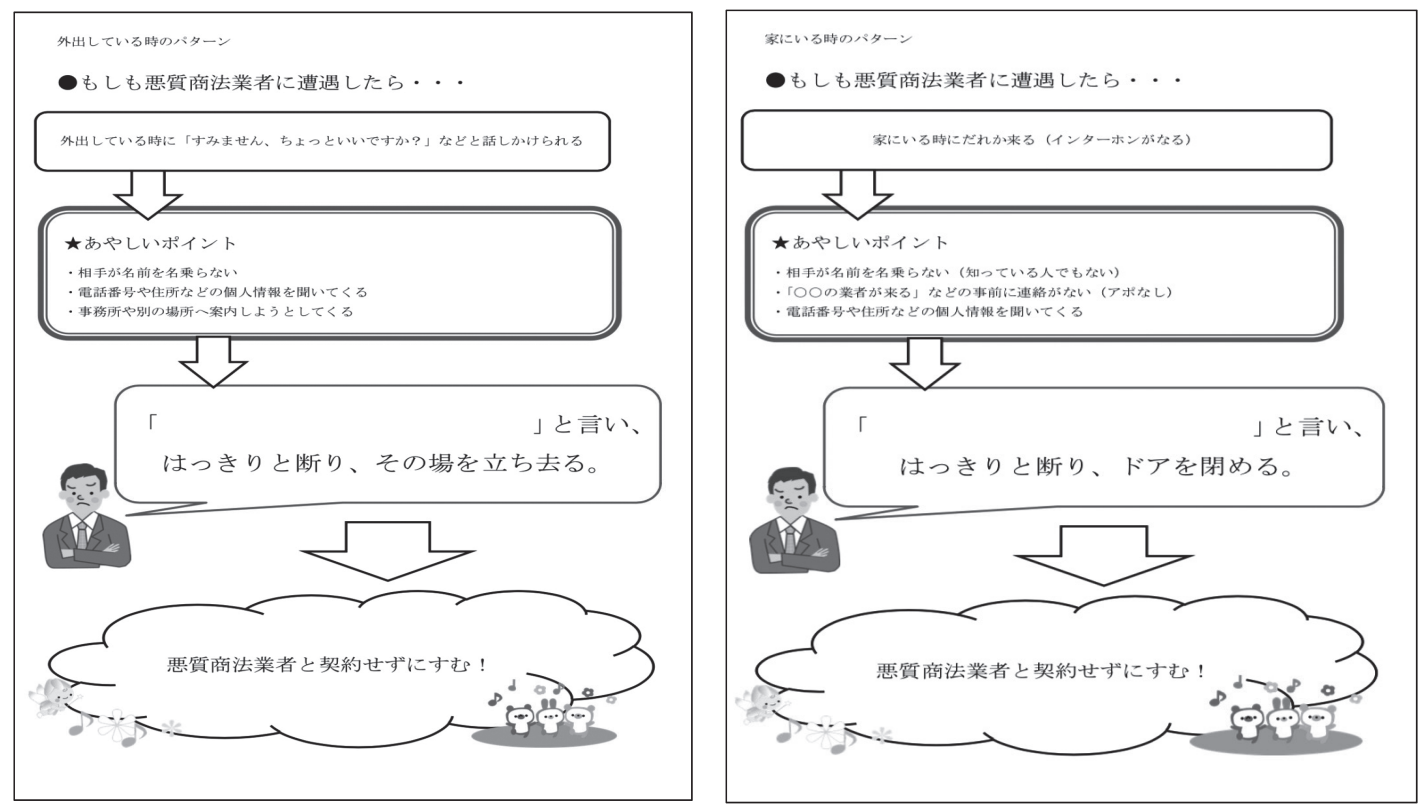

Fig. 2 ルールシート 
（1）悪質商法に関する聞き取りアセスメント： インフォームド・コンセントと同日に悪質商法に関す る聞き取りアセスメントを行った。アセスメントは第 1 著者が対象者に口頭で聞き取りを行った。聞き取っ た内容は、(1) 悪質商法にはどのような種類があるか、 (2) どのような手口で针誘を受けるか、(3)悪質商法の 勧誘を受けた経験はあるか、(4) 悪質商法の勧誘を受 けた際に断れるか、の4つであった。その結果、(1) と (2)の質問に関しては、3名ともに高等学校の現代社会 や家庭科の授業で学習する程度の知識はもつているこ とが確認された。(3)の質問に関しては、全員が悪質 商法の针誘を受けた経験がなかった。(4)に関しては、 対象者 $\mathrm{A} は 「$ 絶対に引つかからない自信がある」、対 象者 B は「実際に悪質商法に遭遇したらうまく対応で きるか不安」、対象者 C は「悪質商法だと思うと全部 が怪しくみえてしまう」と回答した。

( 2 ) ベースライン (baseline; 以下、BL とする) 期：室内を現実場面と仮定し、シミュレーション訓 練を行った。シミュレーション訓練は、「在宅条件」 「外出条件」「その他条件」の 3 条件 10 課題を用いて 行った (Fig. 1参照)。

シミュレーション訓練を開始する前に、第 1 著者が 対象者に向けて (1) 指導中にトレーナーが販売員とし て対象者に話しかけること、(2)訓練中にした契約は あくまで訓練のためのものであり実際に契約したこと にはならないこと、(3)話しかけてくるトレーナーの すべてが販売員ではないことを口頭にて伝えた。その 後、在宅条件、外出条件ともに約 10 分間行った。

在宅条件では、指導室内にセッティングされた自宅 （以下、仮自宅とする）を実際に生活する自宅とする設 定でシミュレーション訓練を行った。MTは対象者に 対して、シミュレーション訓練中は実際と同様にゲー ムをしたり、本を読んだりして過ごしているよう伝え た。仮自宅には、非悪質商法 A の小道具として「○○ 株式会社の人が火災報知器の点検にくる。母より」と いうょうな内容のメモ書きを置いた。シミュレーショ ン訓練が開始したら、販売員役、非販売員役は Fig. 1 に示している課題をランダムに提示した。対象者は提 示された課題に対して、悪質商法かそうでないものか を自分で判断して、対応することが求められた。対象 者が販売員役から悪質商法課題を提示され、標的行動 が生起した場合においても、販売員役は勧誘を 3 回は そのまま行うようにしていた。販売員役は対象者が勧 誘を受けても断り続けた場合、その場を立ち去った。 契約に至った場合は擬似的な契約（例：契約書にサイ
ンをする、事務所へ案内するなど）を交わしてその場 を立ち去った。非販売員役は、あらかじめ各課題に合 わせて「近所の人」「親戚のおじさん」の名札をする ことや、対象者がいる仮自宅に訪祄、名刺を渡すこと をした。名刺は仮自宅に置いてあるメモ書きと同様の 会社名が記述されているものを使用した。非販売員役 は対象者が仮自宅にいる際に訪問し、課題を提示し た。対象者が適切な反応（例：近所の人から回覧板を 受け取る、火災報知器の点検をしてもらうなど）をし た場合、笑顔で挨拶をしてその場を立ち去った。対象 者が悪質商法と同様の反応をした場合は、しつこく対 応することはせず、その場を立ち去った。

外出条件は、指導室内を通勤・通学路や外出先と仮 定して、セッティングをした。その際に MT は対象者 に対して、実際の通勤・通学と同じように過ごすよう 伝えた。それ以外は在宅条件と同様であった。

その他条件は、在宅条件・外出条件のいずれかのシ ミュレーション訓練を行っている最中に、第 1 著者が 予告なしで対象者の携帯電話にメールを送信した。 メールは悪質商法課題と非悪質商法課題のものを 1 通 ずつ送信した。悪質商法課題も非悪質商法課題も同じ メールアドレスからメールを送信していたため、メー ルの内容を読まなければ判断できないようになってい た。悪質商法課題においても非悪質商法課題において も、対象者から返信があった場合は、特別なフィード バックは与えず、第 1 著者からの返信もしなかった。

（3）トレーニング (training; 以下、TR とする) 期： BL 期の結果を受け、対象者 $\mathrm{A} ・ \mathrm{~B}$ にはより得点 が低かった外出条件、対象者 Cには在宅条件を指導し た。トレーニングの構成は (1) ルールの提示、(2) シミュ レーション訓練、(3) MTによるフィードバックの順に 行つた。

(1) ルールの提示：各条件に合わせて作成したビ デオとシートを用いて行った。MTはノート型パーソ ナルコンピューターを使用して対象者にビデオを見せ た。ST はビデオが流される前にシートを配布した。 対象者はビデオを見ながらシートの空白の部分に当て はまる文言を記述した。MTは対象者が記入したシー トをチェックして、記述が正しければ称賛し、誤って いたらもう一度ビデオを確認した。最後に MT は、 シートに記述されている悪質商法と判断するポイント の部分を再度伝え、販売員に注意するよう対象者に伝 えた。

(2)シミュレーション訓練：基本的な手続きは $\mathrm{BL}$ 期と同様であった。在宅条件の悪質商法課題とし 
て「訪問販売 $\mathrm{A} 」$ 、非悪質商法課題として「非悪質商法 A（事前に連絡がある業者：宅配便)」「非悪質商法 A (事前に連絡のある業者：点検作業)」「非悪質商法 B (知っている人が訪ねてくる：近所の人)」を選定した。 選定された課題は 1 セッションにおいて 1 回ずつ提示 した。提示される順番はセッションごとにランダムと した。外出条件の悪質商法課題は「キャッチセールス $\mathrm{B}\lrcorner$ 、非悪質商法課題は「非悪質商法 C (道案内)」「非 悪質商法 C (観光客のカメラ依頼)」「非悪質商法 D (大学院生のアンケート)」を選定した。それ以外は在 宅条件と同様であった。

(3) MTによるフィードバック： シミュレーショ ン訓練終了後、各対象者に MTが個別にフィードバッ クを行った。フィードバックのポイントは、第一に悪 質商法はどの夕イミングで来たか、第二にどのような

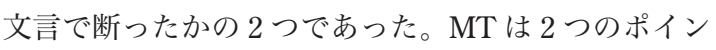
卜に基づいて対象者に質問をし、正しくできていた場 合は称賛し、誤っていた場合は、ルール提示で使用し たシートに記述されている悪質商法と判断するポイン トとその断り方を再度伝えた。

（4）プローブ (probe; 以下、PB とする) 期： BL 期と同様の手続きですべての対象者に在宅条件、 外出条件、その他条件を適用し、指導の効果の測定を 行つた。

（5）対人般化 $\mathrm{PB}$ 期：これまで指導に参加した ことがないトレーナーに対する対人般化の検討を目的 として行った。TR期において指導を行った条件を対象 とし、対象者 $\mathrm{A}$ 、対象者 $\mathrm{B}$ には外出条件、対象者 $\mathrm{C}$ に は在宅条件を行った。それ以外の手続きは BL 期と同 様であった。

（6）社会的妥当性の評価：指導終了後に、社会 的妥当性の評価のためのアンケートを対象者に実施し た。アンケートの質問項目は、「悪質商法の勧誘を断る 行動を、現実場面を想定したシミュレーションを用い て練習したことはよかったですか」「ビデオやプリン 卜などの教材はわかりやすかったですか」「悪質商法 とそうでないものをしつかりと区別することができそ うですか」「実際に悪質商法に勧誘された時に断るこ とができそうですか」「今回の悪質商法対応プログラム での学習はあなたの今後の生活に役立てそうですか」 の全 5 項目だった。それらの質問項目に対して「はい」 「いいえ」の 2 件法と自由記述での回答を求めた。

\section{9. 標的行動の記録・評価方法}

シミュレーション訓練中の様子について、対象者 1 名につき 1 台の動画用カメラ (Panasonic 社製 HX-
DC2-W）を使用し、トレーナーから課題を提示された 際の対象者の反応を記録した。動画用カメラはトレー ナーと対象者の両方が撮影されるようセッティングし た。この撮影したビデオをもとに第 1 著者が、対象者 のトレーナーから課題を提示された際の反応を文書作 成ソフトに逐語的に記述していった。その記述した記 録を Table 1 の評価基準に基づいて点数化した。

\section{0. 観察者間一致率}

セッション全体の約 $30 \%$ を抽出し、ビデオをもと に対象者の標的行動の評価を行い、観察者間一致率を 算出した。観察者一致率の算出は第 1 著者と、研究に 参加していない特別支援教育を専攻する大学院生 1 名 が独立して行った。標的行動の評価は Table 1 の基準 を用いて行い、観察者間一致率は「一致した回数 $\div$ 全 回数 $\times 100 」 と し て$ 算出した。その結果、二者間の一致 率は $92.7 \%$ あった。

\section{III. 結 果}

1. 悪質商法課題における対象者別の結果について

本研究の悪質商法課題における対象者別の得点を Fig. 3 に示した。対象者 $\mathrm{A}$ は BL 期の悪質商法課題では 訪問販売 A 以外の課題において 0 点であり、販売員か らの勧誘を受けても無反応だった。TR期においては 指導開始直後に 3 点となった。第 11 回以降は安定して 3 点であった。 $\mathrm{PB}$ 期では 2 点から 3 点であり、悪質商 法の勧誘を受けても断ることができていた。対人般化 PB 期は最高得点の 3 点であった。

対象者 B の悪質商法課題の結果に関して、BL期の 訪問販売 A と訪問販売 B は 2 点、キャッチセールス A とキャッチセールス B では $0 \sim 1$ 点だった。TR期では 指導開始直後から 3 点となり、そ机以降おおむね 3 点 を維持していた。 $\mathrm{PB}$ 期はキャッチセールス $\mathrm{A}$ とキャッ チセールス $\mathrm{B}$ は 3 点、訪問販売 $\mathrm{A}$ は 2 点だったが第 21 回では 0 点であった。対人般化 $\mathrm{PB}$ 期のキャッチ セールス $\mathrm{B}$ は第 22 回で 3 点、第 23 回で 0 点であった。

対象者 $\mathrm{C}$ の BL 期の悪質商法課題は、在宅条件の訪 問販売 A と訪問販売 B において 2 点であり、販売員が 家に訪問すると家の中に迎え入族を聞く様子がみら 机た。外出条件のキャッチセールス A とキャッチセー ルス Bにおいて 3 点であった。TR期で指導を行った訪 問販売 $\mathrm{A}$ の得点はすべて 3 点、 $\mathrm{PB}$ 期も訪問販売 $\mathrm{A}$ と 訪問販売 $\mathrm{B}$ で 3 点、キャッチセールス $\mathrm{A}$ とキャッチ セールス $\mathrm{B} も 3$ 点だった。対人般化 $\mathrm{PB}$ 期の得点も 3 点 だった。

対象者 $\mathrm{C}$ の本研究の指導中のエピソードとして、 
「自宅にいる際に悪質商法と思われる人物が自宅に訪 ねてきた。インターホン越しに断ることができた」と いう報告があった。

\section{2. 非悪質商法課題における対象者別の結果について}

本研究の非悪質商法課題における対象者別の得点を Fig. 4 に示した。対象者 $\mathrm{A}$ は、BL 期から対人般化 $\mathrm{PB}$ 期まで第 4 回以外では 1 点だった。第 4 回では、課題 を提示されても無反応であった。BL期の他の回では、 例えば第 5 回の非悪質商法 Cでは、道案内をすること や、わからない場合でもはっきりと断るのではなく、 「すみません、僕はわからないので他の方に聞いても らってもいいでしょうか？」と言うことができていた。

対象者 $\mathrm{B}$ は、 $\mathrm{BL}$ 期から対人般化 $\mathrm{PB}$ 期まで一貫して 1 点であった。 BL期から在宅条件と外出条件の $2 つ 0$ 条件で適切な対応ができていた。 TR 期に入り、外出 条件の悪質商法の勧誘を断る行動を指導しても、非悪 質商法課題に対して、道案内をすることや、大学院生 のアンケートに答えるなど、適切に対応することがで きていた。
対象者 C は、すべての課題において BL 期から対人 般化 PB 期まで一貫して 1 点だった。BL 期の時点で、 例えば非悪質商法 Aの点検作業においては、仮自宅に あるメモを参照し、事前連絡があることを確認した上 で点検作業を受け入れることができていた。TR期に 入っても、指導に影響されることなく、悪質商法課題 とは異なる対応をすることができていた。

3. その他条件の対象者別の結果について

本研究のその他条件における対象者別の得点を Fig. 5 に示す。対象者 $\mathrm{A}$ は、BL 期の段階で不当請求・当選 商法に関してメールを返信することはなく 1 点となっ たが、非悪質商法 $\mathrm{E}$ に関してもメールの返信はなく、 0 点となった。これは、指導後も変化することがな かった。

対象者 $\mathrm{B}$ は BL 期では不当請求・当選商法は返信が なかったため、1点であった。PB 期では「せっかくで すがお断りします」というはっきりと断る内容の返信 があり、0 点であった。非悪質商法 $\mathrm{E}$ に関しては、BL 期ではメールの返信がなく 0 点であったが、PB 期に
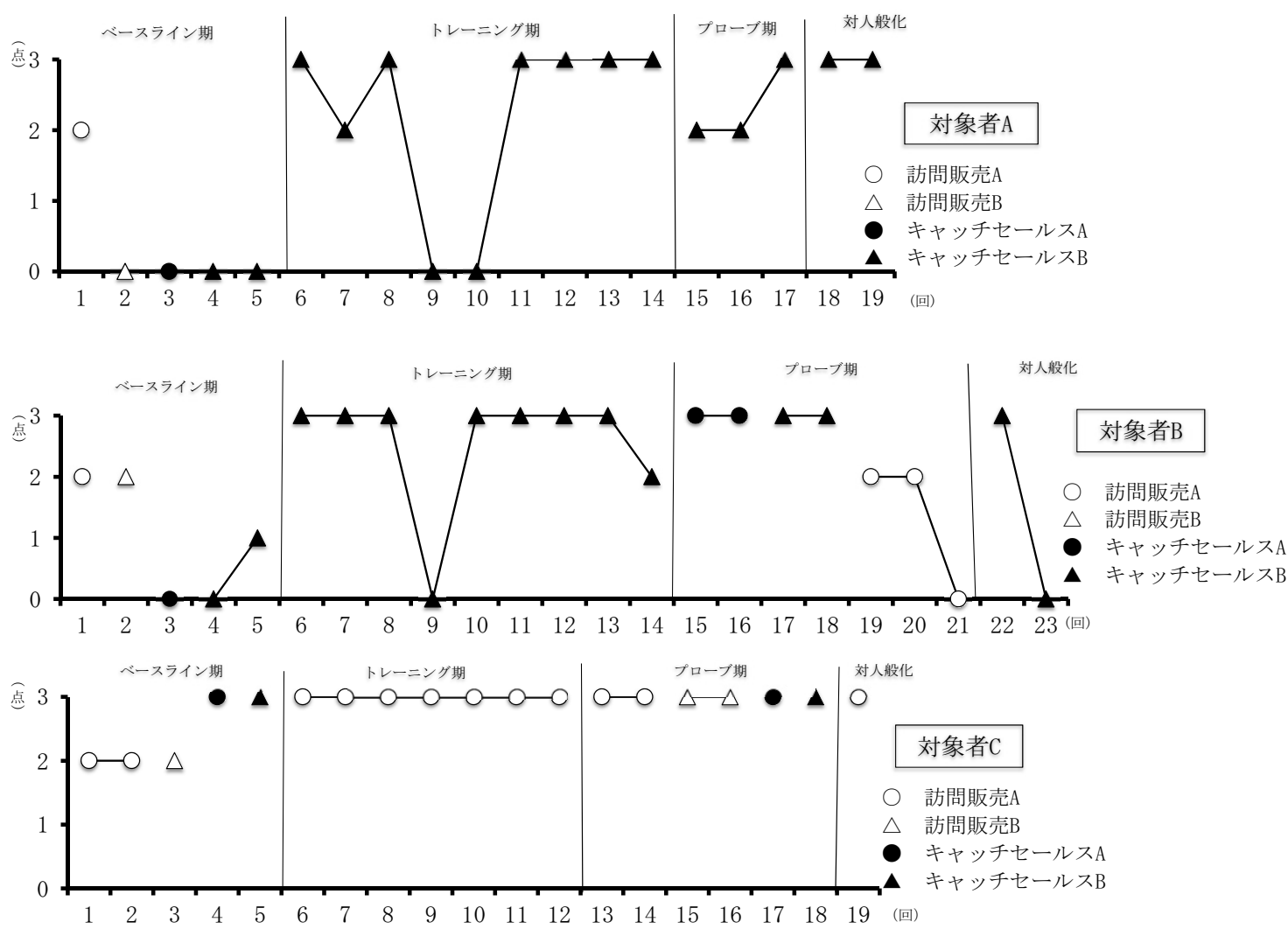

Fig. 3 悪質商法課題における対象者別の得点 


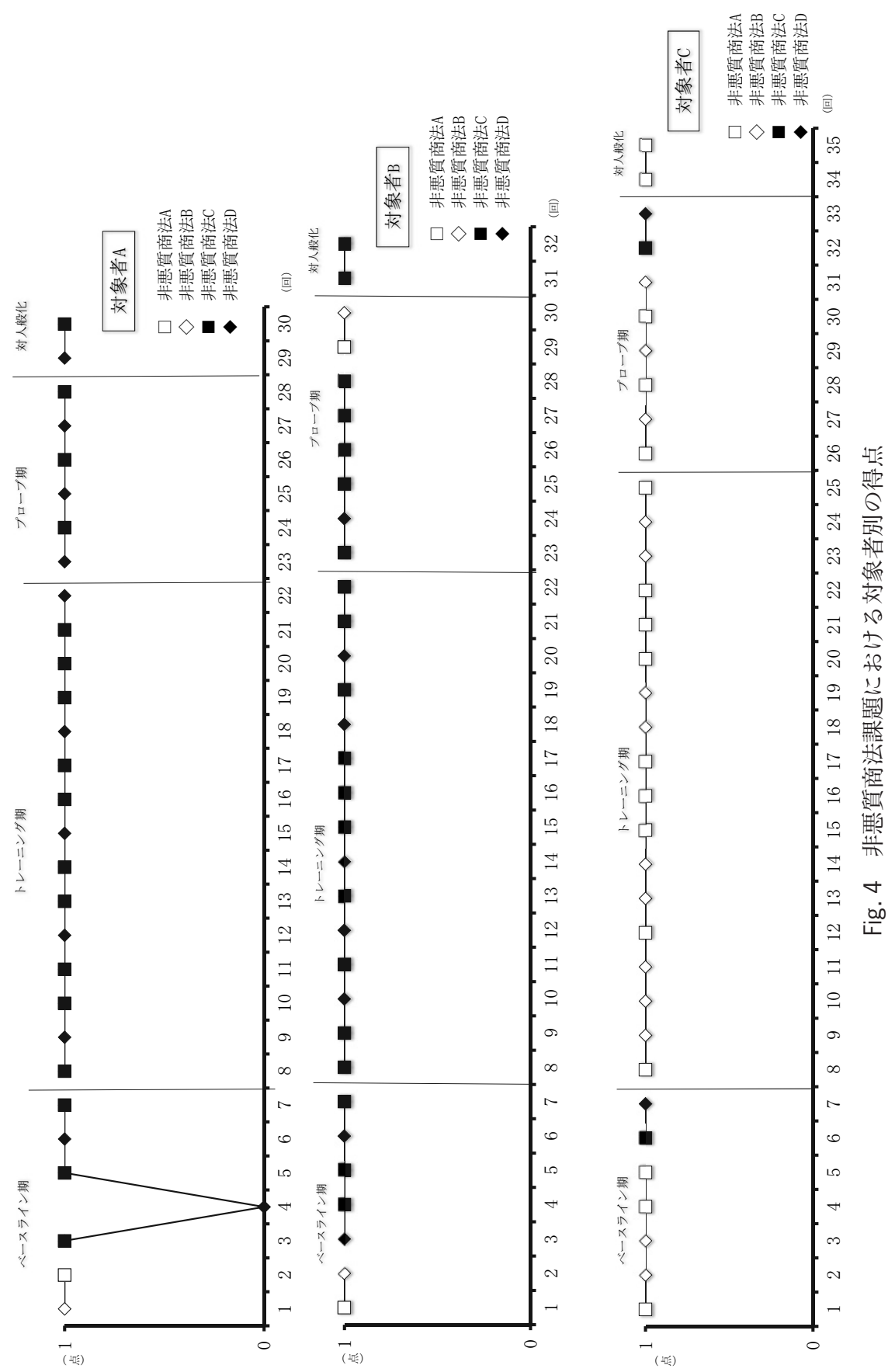


は、「ここで学んだことは非常に役立つものです。次 回、出席します」という内容のメールの返信があり 1 点であった。

対象者 C は、不当請求・当選商法の $\mathrm{BL}$ 期ではメー ルの返信はなく 1 点、指導後の PB 期でも変化はなく 1 点を維持した。非悪質商法 $\mathrm{E}$ は $\mathrm{BL}$ 期は 0 点であつ たが、指導後のPB 期は「勉強したことはとても役立 ちました。次回よろしくお願いします」という内容の 返信メールがあり、1点であった。

\section{4. 社会的妥当性の評価}

社会的妥当性の評価の結果は、すべての対象者がす べての質問項目に対して「はい」と回答していた。自 由記述欄には、対象者 B から「このプログラムは将来 にとても役立つと思いますし、もつと他の人にも行う べきだと思います」という回答を得ることができた。

\section{IV. 考 察}

本研究ではASD のある青年に対して、ルールを用 いて悪質商法の勧誘を断る行動の指導を行い、(1) 悪質 商法の勧誘を断る行動の獲得、(2) 直接指導をしていな い悪質商法に対する般化、(3) 悪質商法と悪質商法では ないものの適切な弁別を検討することを目的とした。

\section{1. 悪質商法の勧誘を断る行動の獲得について}

対象者 $\mathrm{A}$ は、 $\mathrm{BL}$ 期の段階では話しかけても無反応 であった。非悪質商法課題が最高得点となっているた め、悪質商法と非悪質商法を弁別することができてい るといえる。このことから、標的行動の弁別刺激は機
能しているが、反応型を獲得していなかつたと考えら れる。TR期に入った段階で得点は上昇し、指導後の $\mathrm{PB}$ 期においても標的行動が生起していた。対象者 $\mathrm{C}$ は、BL 期と比較して指導開始後の第 6 回には標的行 動の得点が上昇したことから、指導の効果があったと いえる。Malott（1988）はルールの EO としての機能 を強調している。さらに杉山ら (2013) はルールが EO として機能し、行動を制御することができることを指 摘している。本研究で用いたルールは EO として機能 し標的行動を生起させ、「悪質商法との契約を回避で きる」といつた結果の強化価值を高めることができた と考えられる。

2. 直接指導をしていない悪質商法への般化について 対象者 $\mathrm{A}$ は $\mathrm{PB}$ 期にその他条件のみ検討を行った。 その他条件においては、 $\mathrm{BL}$ 期と $\mathrm{PB}$ 期で変化はなく、 指導の効果がなかったと考えられる。対象者 $\mathrm{A}$ におい ては、「メールを返信する行動」が未獲得である可能 性があり、別の介入の必要性が示唆される。しかし、 本研究は BL 期、PB 期ともに回数が 1 回になっている ため、時間帯等をずらして数回テストを行うことが必 要であったといえる。

対象者 B は指導をしていない在宅条件とその他条件 において検討を行った。その結果、在宅条件は BL 期 と $\mathrm{PB}$ 期で点数の変化はなく、指導の効果はみられな かった。しかし、その他条件の PB 期において非悪質

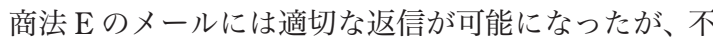
当請求・当選商法においては指導した標的行動が般化
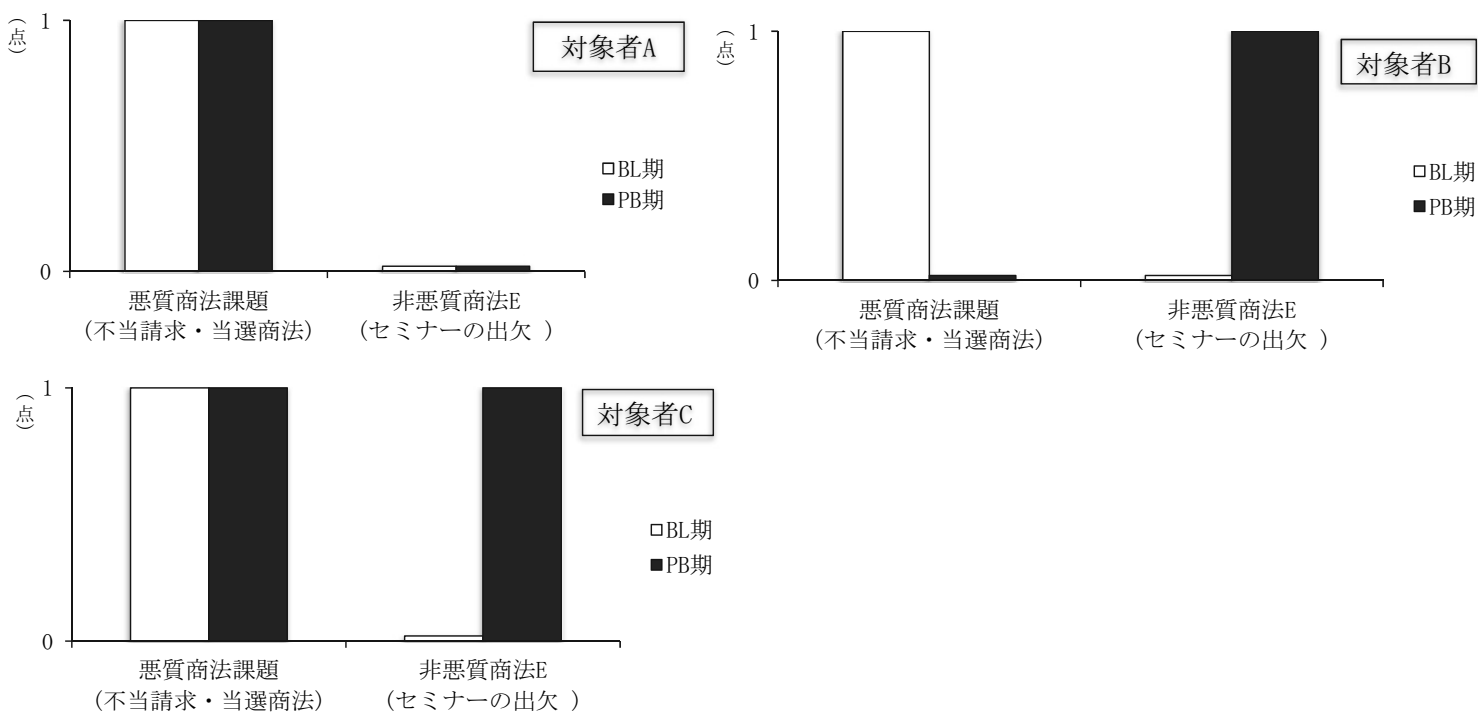

Fig. 5 その他条件における対象者別の得点 
した。この結果から、メールなど他の悪質商法と異な る対応が求められるものは、別の介入が求められるこ とが示唆された。

一方で、対象者 Cにおいては、指導をしていないそ の他条件で、BL 期では不当請求・当選商法と非悪質 商法 $\mathrm{E}$ の両方の課題において返信がなかった。 $\mathrm{PB}$ 期 には不当請求・当選商法は変化がなかったが、非悪質 商法 $\mathrm{E}$ には適切な内容のメールの返信があった。対象 者 $\mathrm{C}$ は、もともと外出条件は指導前の時点で最高得点、 在宅条件では 2 点であり、悪質商法と悪質商法ではな いものを適切に弁別できていたが、その反応型が望ま しくなかったといえる。この結果より、対象者 Cのよ うな対象者に対してはルールを用いた指導をすること により、反応型を修正し、直接指導をしていないその 他条件において標的行動が適切に般化する可能性が示 唆された。

\section{3. 悪質商法課題と非悪質商法課題の適切な弁別と}

\section{対人般化について}

本研究に参加したすべての対象者は、BL 期の段階 で非悪質商法課題には適切に対応することができてい た。TR期になっても悪質商法課題と競合することな く、非悪質商法課題に適切に対応することができた。 さらには、対象者 $\mathrm{A}$ と対象者 $\mathrm{C}$ に関しては指導後の $\mathrm{PB}$ 期、対人般化 $\mathrm{PB}$ 期においても同様に維持すること ができていた。この結果から、標的行動である「悪質 商法の锥誘を断る行動」においてルールを用いた指導 は、「広汎な刺激に対する般化」だけでなく、「悪質商 法と悪質商法ではないものの適切な弁別」にも有効で あることが示唆された。本研究ではルールの提示にビ デオとシートを用いたことが、般化だけでなく弁別に も効果があったと考元られ、Persicke et al. (2013) を 支持する結果となった。この要因として、本研究で使 用したルールの一部として、対象者らが悪質商法の知 識に関して発言していなかった内容を明記したこと が、標的行動を喚起させる重要な要素となったと考え られる。しかし、本研究で用いたルールは行動随伴性 のすべてを記述したルールになっている。このことか ら、悪質商法の知識に関して発言していなかった内容 を明記したことのみが影響したとはいえないため、今 後検討していく必要がある。

一方で、上記の例に該当しない対象者もみられた。 対象者 $\mathrm{B}$ は、 TR 期に標的行動の得点が上昇し指導の 効果がみられていたが、対人般化 $\mathrm{PB}$ 期では得点が下 降した。このことから、対象者 B は指導した人物以外 で効果が示されなかった。松本・大河内（2002）は、
ルールに抵触する随伴性（ルールが正確でない、罰を 回避できないなど）はルールに従う反応を消失させる と述べている。本研究において用いたルールは、販売 員の外見的特徵までを記述した内容ではなかったた め、対象者 B は対人般化がみられなかったと考元られ る。しかし、悪質商法の指導において販売員の外見的 特徵を記述することは、外見で「信頼できそうな人」 と判断したとしても販売員である可能性があるため、 非常に危険なことであるといえる。Stokes and Osnes （1988）は多様な刺激を用いることで般化は促進され ると述べている。このことから、より多くのトレー ナーが販売員として訓練を行うことが対象者 Bには必 要だったと考えられる。

\section{4. 今後の課題と展望}

今後の課題は、 3 点ある。1 点目は悪質商法の勧誘を 断る行動におけるルールを用いた指導の事例を増加す ることである。本研究においては 3 名の対象者が参加 しているものの、 3 名ともに異なる般化の傾向を示し た。指導の効果がどのような般化傾向を示すかを検討 するために、事例を増やす必要がある。

2 点目は、悪質商法の勧誘をはっきりと断った後、 悪質商法の勧誘を受けたことを消費生活センターや 保護者などに報告する行動の形成の必要性である。 Miltenberger et al. (1999）の研究では、犯罪者に遭遇 したことを保護者や教師に報告するまでを指導してい る。本研究は、犯罪被害後の報告行動の指導までには 至らなかったが、その後の犯罪被害を未然に防ぐため には、消費生活センターなどに報告し相談するまでを 指導する必要があると考える。

3 点目は、万が一、悪質商法と契約してしまった場 合の対応方法の指導である。悪質商法の手口は巧妙か つ複雑化、多様化しており、多くの人がその被害に あっている。特に知的能力障害や発達障害のある場合 では、本人の被害認識自体が薄いことや、被害認識は あっても自分が騙されたことが悪いと思ってしまった り、部分的に引け目を感じてなかなか周囲に言えな かったりする場合があり、周囲に相談できないままに なっていることがあるという（名川・堀江・佐藤, 2005)。 このため、万が一被害にあってしまった時に早期に クーリングオフをすることや、消費生活センターや警 察への連絡などの対応方法についても、指導の必要性 があるといえよう。

以上の課題から、今後の展望として、本研究のよう な悪質商法の被害を未然に予防する予防的行動の指 導、万が一被害にあってしまった時の対処的行動の指 
導の 2 つの指導の観点から研究を進めていくことで、 今後の自己防衛スキルの研究の発展や、障害のある人 の犯罪被害の拡大防止に貢献できると考える。

\section{付 記}

本論文の一部は、日本特殊教育学会第 55 回年次大 会で発表された。

\section{註}

1) Laraway, Snycerski, Michael, and Poling (2003) は EO に代わる用語として、動機づけ操作 (motivating operation; 以下、MO とする) を提案している。MO は従来の EO に加え、無効操作 (abolishing operation; 以下、AO とする) を含めた概念になる。本研 究で用いたルールは EO の機能はあるが、AO とし ての機能はないと考えられる。このため、より厳 密な表現になるよう、従来の EO という用語を本 研究では使用することとした。

\section{文 献}

Howlin, P. (2000) Outcome in adult life for more able individuals with autism or Asperger syndrome. Autism, 4, 63-83.

井澤信三 (2003) 自閉症児における問題状況を解決す るための社会的技能の獲得と般化一生態学的調查に 基づいた「ルール制御」による指導とその効果一. 発達心理臨床研究, 9, 1-7.

井澤信三・山本真也 ・半田 健 (2011) 高機能広汎性 発達障害青年における社会的コミュニケーション行 動支援に関する文献的検討. 兵庫教育大学研究紀 要, 38, 63-70.

上迫 明 (2008) “特定商取引に関する法律” と現代の 商取引上のトラブルに関する一考察. 福山大学経済 学論集, 33(1), 141-171.

警察庁 (2018) 悪質商法の被害にあわないために. 警 察庁 Web サイト, 2018 年 4 月 1 日, https://www.npa. go.jp/bureau/safetylife/keizai/index.html（2018 年 7 月 6 日閲覧).

Laraway, S., Snycerski, S., Michael, J., \& Poling, A. (2003) Motivating operations and terms to described them: Some further refinements. Journal of Applied Behavior Analysis. 36, 407-414.

Malott, R. W. (1988) Rule-governed behavior and behavioral anthropology. The Behavior Analyst, 2 (Fall), 181203.
松本明生・大河内浩人（2002）ルール支配行動一自 己ルールとスケジュールパフォーマンスの機能的関 係一. 行動分析学研究, 17, 20-31.

Michael, J. (1982) Distinguishing between discriminative and motivational functions of stimuli. Journal of the Experimental Analysis of Behavior, 37, 149-155.

Miltenberger, R. G., Roberts, J. A., Ellingson, S., Galensky, T., Rapp, J. T., Long, E. S., \& Lumley, V. A. (1999) Training and generalization of sexual abuse prevention skills for women with mental retardation. Journal of Applied Behavior Analysis, 32, 385-388.

名川 勝・堀江まゆみ・佐藤彰一 (2005) 知的障害の ある人の消費トラブルに対する支援と研究. 発達障 害研究, 27, 175-182.

日本弁護士連合会・高齢者障害者の権利に関する委員 会・消費者問題対策委員会 (2008) 消費者・福祉部門 の連携づくり一高齢者・障がいのある人の消費者被 害の防止・救済のために一. 日本弁護士連合会, 2008 年 11 月 27 日, https://www.nichibenren.or.jp/library/ja/ committee/list/data/syouhisya_fukushi_renkei_houkoku_ 001.pdf (2017 年 12 月 16 日閲覧).

大石剛一郎 (2005) 発達障害のある人に関する裁判に おける権利擁護の状況と課題一発達障害のある人の 裁判でのセーフティーネットについて一. 発達障害 研究, 27, 167-174.

Persicke, A., Tarbox, J., Ranick, J., \& St. Clair, M. (2013) Teaching children with autism to detect and respond to sarcasm. Research in Autism Spectrum Disorders, 7, 193198.

Poche, C., Brouwer, R., \& Swearington, M. (1981) Teaching self-protection to young children. Journal of Applied Behavior Analysis, 14, 169-176.

佐分厚子 (2011) 地域生活における障がい者や高齢者 の消費者被害未然防止・再発防止に関する支援. 評 論・社会科学, 98, 95-124.

Skinner, B. F. (1969) Contingencies of reinforcement: A theoretical analysis. Appleton-Century-Crofts, New York.

Stokes, T. F. \& Osnes, P. G. (1988) The developing applied technology of generalization and maintenance. In R. Horner, G. Dunlap, \& R. L. Koegel (Eds.), Generalization and maintenance: Life-style changes in applied settings. Paul H. Brookes, Baltimore, Maryland, 5-19. 小林重雄・加藤哲文監訳 (1994) 自閉症, 発達障害者 の社会参加を目指して.二瓶社, 1-19.

須藤邦彦 (2009) 自閉性障害児における援助行動の随 
伴性整備一ルールの設定による援助文脈での強化の 予測と行動制御一. LD 研究, 18, 261-273.

杉山尚子・島宗 理・佐藤方哉・マロット, R. W.・マ

ロット, M. E. (2013) 第 23 章ルール支配行動の理

論, 行動分析学入門. 産業図書, 309-325.
Wurtele, K. S. (1990) Teaching personal safety skills to four-year-old children: A behavioral approach. Behavior Therapy, 21, 25-32.

- 2018.2.8 受稿, 2020.8.22 受理一

Jpn. J. Spec. Educ., 58 (4), 269-282, 2021

\title{
Practical Research
}

\section{Acquisition and Generalization by Young Adults With Autism Spectrum Disorders of the Behavior of Refusing Dishonest Business Solicitations}

\author{
Takami YAMAмото* and Shinzo IsAWA** \\ * Behavioral Support Service for Developmental Disorders TRIAL \\ (Kobe, 658-0053) \\ ** Hyogo University of Teacher Education
}

(Kato, 673-1494)

\begin{abstract}
The purpose of the present study was to instruct 3 young adults (17 years old: 1;20 years old: 2 ) with autism spectrum disorder in the behavior of refusing solicitations for malicious businesses, and to examine (a) acquisition of the behavior of refusing to be solicited by malicious businesses, (b) generalization to malicious businesses that had not been directly taught, and (c) appropriate discrimination between malicious businesses and non-malicious businesses. The instruction was conducted in the following order: presentation of rules, simulation training, and feedback from the trainer. For the presentation of rules, the participants viewed a video of how to refuse a malicious business solicitation and a rule sheet. In the simulation training, the participants were trained in an out-of-home condition and a home-based condition. For each condition, a pernicious sales task and a non-pernicious sales task were prepared. Feedback was given by the trainer after the training. Of the 3 participants, 2 succeeded in interpersonal generalization, 1 also succeeded in conditional generalization, and episodes of generalization in actual situations were confirmed for 1 participant.
\end{abstract}

Key Words: crime prevention, consumer education, malicious business, rule-governed behavior, young adults with autism spectrum disorder 